\title{
THE IMPORTANCE OF ATCO GAS AND PIPELINES: A RESPONSE TO H. MARTIN KAY
}

\author{
Alice WoOLLEY*
}

\section{INTRODUCTION}

H. Martin Kay has responded to my case comment ${ }^{1}$ on the Supreme Court of Canada's decision in ATCO Gas and Pipelines Ltd. v. Alberta (Energy and Utilities Board). ${ }^{2} \mathrm{Mr}$. Kay asserts that my comment "misstates significant aspects of the rate-setting process"3 and, as a result, overstates the importance of the Court's decision. In particular, he takes issue with my analysis of the Court's approach to the standard of review, and also with my analysis of the treatment of disposition of utility assets subsequent to the Court's decision.

In the comments below, I seek to provide additional support for my argument that AGPL is not a narrow decision and that it makes it impossible for the Alberta Energy and Utilities Board (AEUB) to properly protect the public interest on any future application by a utility to dispose of assets currently included in rate base. My central point in this response, which goes beyond my original case comment, is that the legislature should take the opportunity presented by Bill 46, Alberta Utilities Commission Act, ${ }^{4}$ to grant the new Alberta Utilities Commission (AUC) clear jurisdiction to allocate proceeds in conjunction with an application for disposition of utility assets. Absent such legislative clarification, the AUC, like its soon to be predecessor the AEUB, will face significant challenges in its oversight of Alberta utilities. Through an express legislative grant of authority to condition a disposition of assets on a proper allocation of proceeds, the new Commission will be able to provide adequate protection for the public interest.

\section{STANDARD OF REVIEW}

Mr. Kay suggests that my criticism of the Court's approach to the standard of review confuses the Board's "acknowledged expertise when acting within the scope of its powers with the application of that expertise in determining the scope of its authority." $\mathrm{Mr}$. Kay contends that the Board's expertise "does not determine the initial question of whether it is acting within its jurisdiction." 6 While this latter point is obviously correct (statutory authority determines the regulator's jurisdiction), the point of my criticism is that to partition the Board's expertise, so that it has acknowledged expertise about questions within its jurisdiction, and no expertise at all about the scope of its authority, is artificial and undesirable.

Assistant Professor, Faculty of Law, University of Calgary.

Alice Woolley, “'Practical Necessity’ or 'Highly Sophisticated Opportunism?' Judicial Review and Rate Regulation After ATCO Gas and Pipelines Ltd. v. Alberta (Energy and Utilities Board) (2006) 44 Alta. L. Rev. 445.

2006 SCC 4, [2006] 1 S.C.R. 140 [AGPL].

H. Martin Kay, Q.C., “On ATCO Gas and Pipelines: A Reply to Professor Woolley” (2007) 45 Alta. L. Rev. 257 at 258.

$4 \quad$ 3rd Sess., 26th Leg., Alberta, 2007 (first reading 14 June 2007).

Supra note 3 at 258.

Ibid. 
Schemes of utility rate regulation are complex, and require intertwining the economic principles of the free market with the special considerations that apply to regulated industries in a particular context, in this case, natural gas. With respect to utility assets, relevant considerations include, inter alia, the general regulatory goal of achieving just and reasonable rates, treatment of assets in a general rate application, the prohibition on retroactive rate-making, the relationship between the assets and the utility's rate of return, and the need for the utility to be incentivized towards efficiency and business prudence with respect to its dealings with its assets. All of these considerations come into play when the Board determines what is necessary to set just and reasonable rates and, as part of that ratesetting function, to approve (or not) proposed dispositions of utility assets. While the Board certainly does not have a monopoly on the application of these considerations, its expertise to do so carries on regardless of whether the question is jurisdictional — what the Board is allowed to do under the statute in order to set just and reasonable rates and review a proposed asset disposition — or legal/factual — what the Board should do pursuant to those powers to set just and reasonable rates and review a proposed asset disposition. Its expertise should be given respect and deference, even when what is at issue is the extent of its jurisdiction. ${ }^{7}$

\section{Public Interest}

Mr. Kay also suggests that I am attempting to give the Board what "the Legislature has not: the authority for the AEUB to set conditions in the public interest to expand the tribunal's jurisdiction." ${ }^{8}$ What Mr. Kay does not explain, however, is why no account can be taken of the fact that the legislature itself expressly granted the Board power to make conditions in the public interest as part of its statutory authority. Under the majority's interpretation, nothing follows from the express grant of that jurisdiction beyond that which would flow from the ordinary principle of statutory interpretation that a regulator may do that

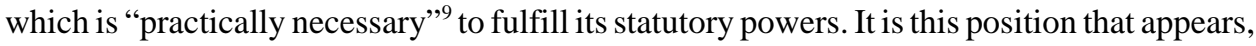
with respect, to fail to take account of the jurisdiction expressly given to the Board by the legislature.

\section{Property Rights, Rate Base, AND the Prevention of HARM}

In his response, Mr. Kay reasserts ATCO’s position, accepted by the Court, that the utility has unqualified property rights in the assets that it owns. He does not explain, however, how

The pragmatic and functional analysis allows the court to take this approach and, as I noted in my original case comment, the court has been willing to be deferential even where questions are characterized as “jurisdictional.” See Woolley, supra note 1 at n. 36. My concern, which goes well beyond the $A G P L$ decision, is that in applying the pragmatic and functional analysis the courts are placing too much emphasis on the nature of the question, rather than on the nature of the tribunal's expertise. For a discussion of the over-arching problem with correctness review see David Dyzenhaus, “Constituting the Rule of Law: Fundamental Values in Administrative Law” (2002) 27 Queen’s L.J. 445. Dyzenhaus argues that a pure correctness review, in which no deference is given to the decision maker, is inconsistent with the fundamental values of our legal system. In every case the reasons given by a decision maker must be accorded serious weight.

$8 \quad$ Supra note 3 at 259.

$9 \quad$ AGPL, supra note 2 at para. 77. 
this unqualified right is balanced with the position, taken by ATCO in prior hearings, ${ }^{10}$ that a loss of value in a utility asset arising from it being "stranded or underutilized"11 (such as no longer providing utility service) should be borne by ratepayers.

Mr. Kay further suggests that since ratepayers do not pay rates adjusted for the current value of assets, it is unfair to characterize the risk associated with the assets as lying with ratepayers, and attempts to draw a distinction between "core" and other utility assets, suggesting that different considerations arise from the removal of non-core assets from rate base. $^{12}$

Unfortunately, these points miss the central issue: there is no regular scrutiny of the assets previously included in the utility's rate base. While, over the total rate base, fluctuations in the value of assets used for utility service may benefit either ratepayers or utilities, the retention of assets in rate base that are no longer used or useful for utility service will in most cases only benefit the utility. Under current practice there is little to stop the utility from leaving an asset which it is no longer using in rate base and continuing to earn a rate of return on that asset. Prior to AGPL, this possibility was to some extent countered by the sharing of proceeds when a valuable asset was disposed of (those proceeds counter-balanced the rate of return earned on assets which are no longer used or required to be used but remain in rate base). That counter-balancing effect does not exist subsequent to AGPL and, without legislative amendment, should lead the Board to regular and significant scrutiny of the assets previously included in the utility's rate base.

It is also not clear how the distinction between "core" and other utility assets furthers the debate. The word "core" does not appear anywhere in the Gas Utilities Act, ${ }^{13}$ the Public Utilities Board Act, ${ }^{14}$ the Electric Utilities Act, ${ }^{15}$ or the Alberta Energy and Utilities Board Act. ${ }^{16}$ Pursuant to the legislative scheme of utility rate regulation, an asset's treatment in rate base, or at the point of disposition, depends on whether it is used or required to be used, not on whether it is or is not core to the utility's operations. If an asset is no longer used or required to be used then it should not be included in rate base, whether or not it was once core to the utility's business.

Finally, Mr. Kay's rebuttal does not address the issue that has troubled regulators since the AGPL decision: without the power to allocate proceeds from disposition of an asset, how does the regulator provide proper incentives to utilities to ensure that they do not use the structure of cost-of-service rate-making to engage in speculative business ventures? In particular, how does the regulator ensure that the utility does not keep low-value assets in 
rate base while selling high-value assets from which it can earn considerable proceeds of disposition?

In Ontario, the Ontario Energy Board (OEB) grappled with this problem in a recent decision with respect to the rate effects that should result from Enbridge Gas Distribution Inc's disposition of cushion gas. ${ }^{17}$ The OEB reviewed the AGPL decision and, after noting that the OEB does not have the power to approve or prevent sales of utility assets, held that $A G P L$ did not prevent it from allocating proceeds of asset disposition in a normal rate hearing. The OEB noted the thrust of $A G P L$, but stated that it "must be able to incent and disincent utilities through its ratemaking powers." ${ }^{18}$ Otherwise it will not be possible to "curb any inclination a utility may have to sell assets which are needed for provision of the regulated service, but which have appreciated in value over the years." ${ }^{19}$ The OEB said that this can be done in Alberta by simply denying approval of the sale, but in Ontario that incentive can, and must, occur through an after-the-fact allocation of the proceeds. The OEB stated that doing so was an exercise of their “powers to set just and reasonable rates," ${ }^{20}$ not an exercise in confiscation. In the result, OEB declined to exercise its power to allocate proceeds on the facts of that case, but it was unequivocal in holding that the power both existed and was necessary to ensure the achievement of a scheme of just and reasonable rates. $^{21}$

In Alberta the issue has been raised squarely by ATCO's argument that the Carbon gas storage facility, which has been in regulated service since 1959, is no longer subject to the Board's jurisdiction. ${ }^{22}$ ATCO's argument, which it has been making since at least 2001, rests on the position that gas storage is now a competitive business in Alberta, and the provision of gas storage, at least since 2003, is not within the mandate of ATCO as a distribution utility. ${ }^{23}$ The Board has rejected ATCO's position, however, noting that throughout Carbon's life it has been used both to provide utility service and to generate revenue for the benefit of ratepayers. $^{24}$ The Board also noted that as recently as 1996, ATCO expanded Carbon and included the costs of the expansion in rate base..$^{25}$ The Board found, therefore, that even without the need for Carbon to provide utility service, the continued revenue generation at Carbon placed the facility within the "used or required to be used"26 standard and justified treating the facility as a utility asset. If ATCO nonetheless wants to move Carbon out of rate base then it will be required to apply to the Board for approval under the asset disposition provisions that were at issue in $A G P L .^{27}$

OEB, Decision and Order, OEB File No. EB-2005-0211, EB-2006-0081 (30 January 2007), online: OEB <http://www.oeb.gov.on.ca/documents/cases/EB-2005-0211/decision_order_uniongas_ cushioned gas_appendices_20070130.pdf>.

Ibid. at 15.

Ibid.

Ibid.

OEB, Decision and Order, OEB File No. EB-2005-0211 (27 June 2007), supra note 17 at Appendix A. AEUB, Decision 2007-005: ATCO Gas South, Carbon Facilities Part I Module - Jurisdiction (2005/2006 Carbon Storage Plan) (5 February 2007), online: AEUB <http://www.eub.ca/docs/ documents/decisions/2007/2007-005.pdf>.

Ibid. at 7-8.

Ibid. at 20.

Ibid. at 4.

Ibid. at $15 \mathrm{ff}$.

Ibid. at 33-34; see Gas Utitlities Act, supra note 13, s. 26(2)(d)(i). 
The fairest and best result in this case would be to allow ATCO to remove Carbon from rate base; it is an unwarranted stretch of the concept of "used or required to be used" to include in rate base an asset which provides no direct benefit to its utility customers other than an economic return. Removal from rate base should be accompanied by a financial payment from ATCO to ratepayers both to address the negative consequences for customers arising from the sale and, more importantly, to provide incentive for ATCO not to engage in speculative activities. While there is no particular reason to believe that ATCO has engaged in speculative conduct with the Carbon asset, and the change in its status as a utility asset appears to have arisen from the shift towards greater deregulation of natural gas, the expansion of an asset within rate base in 1996 followed by an attempt to move the asset out of regulation only four years later gives reason for regulatory concern.

Ultimately, utilities need to be incentivized to put only those assets into rate base that are necessary for utility service. Utilities should be discouraged from buying an asset that is marginally related to utility services, keeping it in rate base should it not become as profitable as expected, and moving it out of rate base if it is as or more profitable than expected. Ensuring that a payment is made to ratepayers when Carbon is moved out of rate base provides a proper disincentive to that type of conduct in the future.

The problem, though, is as to whether $A G P L$ allows this result to take place. As outlined in my original case comment, it is not obvious that the conditioning powers given by the Court to the Board are sufficient to allow what might in effect be an allocation of proceeds to ratepayers. And it seems clear that the Board does not have the jurisdiction to do so without convening a full (not to mention costly and time-consuming) rate hearing. As a consequence, the Board may well require ATCO to keep Carbon in rate base despite the tangential relationship of the asset to the utility services that ATCO is providing as a distribution utility.

It would give greater regulatory certainty, and clearly authorize the desirable and fair result in this and like cases, were the Board's jurisdiction clarified by the legislature to allow it to allocate proceeds as a condition of an asset disposition where necessary to ensure that future rates are just and reasonable.

\section{CONCLUSION}

Mr. Kay is incorrect in his attempt to narrow the implications of $A G P L$. The judgment makes determinations of fundamental points of principle such as "ownership of the assets is clearly that of the utility; ownership of the asset and entitlement to profits or losses upon its realization are one and the same" 28 and "allowing the Board to confiscate the net gain of the 
sale under the pretence of protecting rate-paying customers and acting in the 'public interest' would be a serious misconception of the powers of the Board to approve a sale." ${ }^{29}$ The implications of these principles for the governance of the utility follow. The decision's implications should be adjusted for or corrected through legislative amendment. The government should grant to the AUC the power that the Supreme Court would not, the power that the AUC will need to ensure just and reasonable rates and economic efficiency, and that other regulators such as the OEB assume they still have. 